\title{
How's Prospect of Digital Banking in Indonesia? Notes From Islamic Views, Economic Value Added for Banking Industry, and Changing Costumer Behavior
}

\author{
Myrna Anggarani \\ School Of Stratejic And Global Studies \\ University of Indonesia \\ email : anggarani.myrna@yahoo.com \\ Mohamad Soleh Nurzaman \\ School Of Stratejic And Global Studies \\ University of Indonesia \\ email : ms.nurzaman@ui.ac.id
}

\begin{abstract}
This study aims describe prospects of digital banking in Indonesia. Digital banking has prospect of being able to increase value added for banks, and also change consumer behavior. Moreover, this study also explain how Islamic views to technological developments, especially the use of digital banking for customer's financial needs. The development of digital banking is important for banking industry. Digital banking has emerged to make transaction easier for customers and to get access to various financial information. This study uses descriptive qualitative analytic methods. Data collection uses documents in the form of literature which related to the theme of the study.
\end{abstract}

Keywords : Digital Banking, Islamic Views, Customer Behavior

\begin{abstract}
Abstrak
Tujuan dari kajian ini adalah mendeskripsikan prospek perbankan digital di Indonesia. Perbankan digital memiliki prospek untuk dapat meningkatkan nilai tambah bagi perbankan, dan juga dapat merubah perilaku konsumen, dalam hal ini adalah nasabah. Kemudian, kajian ini juga akan menjelaskan bagaimana pandangan Islam terhadap perkembangan teknologi, khususnya penggunaan perbankan digital untuk keperluan finansial nasabah. Perkembangan perbankan digital merupakan hal penting dalam dunia perbankan. Perbankan digital muncul untuk membuat nasabah dapat lebih mudah mengakses berbaga informasi. Kajian ini menggunakan metode kualitatif deskritif analitik. Pengumpulan data menggunakan dokumen berupa literatur yang terkait dengan tema kajian.
\end{abstract}

Kata Kunci : perbankan digital, pandangan Islam, perilaku konsumen 


\section{INTRODUCTION}

Along with global economic growth, technological advances are inevitable. The scientist create and innovate technology which can simplify human life. One of technology progress is development of digital banking. Digital banking is full digitization of banks and its all activities such as balance inquiry, transfer, digital payment, and other. Those activities can cover a wide range of areas, including banking business services. The existence of digital banking will encourage economic growth and increase the competitiveness of products and services both at the micro and macro level.

Digital lifestyle is growing by the time and it's becoming a trend for society due to the encouragement of the rapid development of information technology. This is a new challenge for banking industry to deliver innovations that are right on target. So, banking industry will not lose it's business prestige and reputation in the midst of intense economic competition.

Digital banking aims to improve the quality of service to customers more effectively and efficiently on an ongoing basis. It services are also used as an increasingly technological development. Digital banking provides the ability for user to access financial data through computer, mobile phone, and Automated Teller Machine (ATM).

Rapid digitalization has made the banking world change its business strategy by placing technology as a key element for their product and service innovation process. With this increasingly sophisticated information technology network, the relationship between banks and their customers is more closer, more efficient, efficient, fast and cheap.

Banking industry must encourage various information technology innovations which give benefit to bank itself and the society. Furthermoer, banking industry continues to innovate to deliver excellent service to its customers. In addition, banks also continue to provide added value to the public through digital-based banking solutions.

Fulfill customer needs for increase banking growth and banking finance, the bank strives to maximize services through digital banking which in the modern era can be a major alternative for mobile banking users. Implementing digital banking application then the Islamic bank must be able to change the model marketing and management models of Islamic banks.

Improve bank's performance, bank must be able to develop their services. The improvement of the service will have a positive impact on the financial performance of the bank itself. For developing this performance, bank must also be able to provide security for customers in the use of digital banking.

Growth of digital banking is happening all over the world, including in Indonesia. This paper will describe how the prospect of digital banking in Indonesia. The prospect will be discussed from an Islamic point of view, economic value added for banking industry, and changing customer behavior which related to the concept cashless society.

\section{LITERATURE REVIEW}

\section{Digital Banking}

Bank provides digital banking services to customers by providing mobile banking applications and electronic money. Riswandi (2005) explained mobile banking is an electronic-based service that allows users to conduct financial transactions using smartphones. Through mobile banking, users can conduct various financial transactions without having to come to the bank. This is a breakthrough to be able to provide bank service innovation to customers.

Furthermore, based on McKinsey \& Company research ( 2019 ) provide that digital banking in Indonesia is well-developed. Customer are increasingly open to digital channels 
and digitally active customer bring more economic value to their bank. However, it can be build loyalty to their existing customers and attract to their new customers. Furthermore, McKinsey noted there are three trends will make banking industry more attractive in Indonesia. First, increasingly diverse relationship between bank and customer. Second, Indonesia people will open minded to digital banking. Its survey noted, 55 percent of nondigital bank customer will using digital banking product within six months. Around 50 percent of all respondents wanted to consider move to bank even their aren't have physical office. Third, customer who use digital banking are more "valuable". McKinsey noted digital customers are more loyal than non-digital customers. To attract and satisfy customer, bank must be able to adopt a customer-focus minded and redesign the experience of their customer.

Based on regulation of Financial Services Authority ( OJK ) number 12/POJK.03/2018 regarding the Administration of Digital Banking by Commercial Banks, Authority allows banks to promote and provide digital banking services for customer by use delivery channel. In addition, Authority states that banks need to increase effectiveness, efficiency, and optimal services for customers. The service is by providing services which is easily accessed by customers. With the improvement of these services, banks can further enhance their business strategies that are more targeted.

Furthermore, OJK explained the digital banking technology would improve banks intermediation function efficiency, but from individual bank perspectives, they have to balance the positive effect of digital banking technology adoption on their funding and liquidity efficiency versus the negative effect to bank financial performance efficiency. Research focus on bank efficiency from the perspectives of the bank as financial intermediary institutions, as the profit-oriented institution as well as the payment services and resources allocation in the economy. The improvement of banks efficiency could be from their ability to improve their productivity and their business process or because of the economics of scale effect of their business expansion.

Tayibnapis, Wuryaningsih, and Gora (2018) found that digital technology is proven to play a strategic role in providing goods and services in a convenient, practical, cheaper, faster time-saving and labor-intesive way. Digital economy can be one of stimulus of economic growth. The research used qualitative research, since it explained the digital economy phenomenon of internet users, the rapid development of financial technology and the customers needed. This research analyze the condition and problems of existing economy and observe the phenomenon of digital economy in Indonesia.

\section{METHODE}

This study use qualitative descriptive analytic approach. Denzin and Lincoln (1994) in Yusuf (2014), explained qualitative research is multi-method in focus, involving an interpretative, naturalistic approach to its subject matter. This means that qualitative research study things in their natural settings, attempting to make sense or interpret phenomenon in terms of the meaning people bring to them. Qualitative research involves the studied use and collection of a variety of empirical materials case study, personal experience, introspective, life story interview, observational, historical, interactional, and visual tests that describe routine and problematic moments and meaning in life. Qualitative methods can also be interpreted, namely by collecting and analyzing data in the form of words, the actions of humans, and researchers doesn't need to calculate the data.

The object of this research is digital banking in Indonesia. Digital banking is an interesting object to discuss because it's can motivate customers to be more loyal and become their part of the modern lifestyle. Related to this topic, Ministry of Communication and 
Information Technology of Republic Indonesia predicted in 2020 the projected value of ecommerce transactions in Indonesia could reach 130 billion. Increase of e-commerce transactions will also improve non-cash payment systems in digital banking. Furthermore, it's also opens an opportunity for banks to expand their business and market reach.

The type of data collected include journal, news, authority publication, books, and other which related to the topic. Data collection techniques carried out by documentations. Discussion on digital banking is a contemporary topic, so literatures used from early decade.

The analysis technique used is descriptive analysis which analyzes the results in the form of descriptive words derived from journal, news, authority publication, books, and other. After the data is obtained, then analyzed with descriptive-qualitative techniques. Descriptive analysis is used to describe digital banking. Qualitative data analysis is an effort made by working with data, organizing data, finding patterns, discovering what is important and what is learned and deciding what can be told to others.

Data analysis uses the deductive method, which is a discussion that begins with the general nature of the research results and then ends with a specific conclusion. The author observes general problems and then draws conclusions that are specific. In this case, the authors observe the events that exist then compare with related theories. After that is analyzed and finally drawn a conclusion that is relevant to the topic of discussion.

\section{RESULT AND DISCUSSION}

\section{Islamic Views}

Islamic banking as one of the economic sectors which is the wheel of funds circulation in a country must well-develop, follow market needs, and must be in comply with sharia principles. Islamic banking must always be the primary choice of individuals in conducting payment activities and other economic activities. To achieve these targets and objectives, banks must carry out sustainable for innovation in accordance with their needs in order to facilitate customers to fulfill all their economic activities. Application technology in banking, called digital banking, is a banking service that utilizes digital technology to meet customer needs to realize the digital economy.

Islamic law or sharia regulated about obligatory, sunnah, mubah, makruh, and haram (Zahro, 2016). The rules of Islamic law are carried out every time the implementation of human activities. Islam is a religion that gives many conveniences. This facility is also included in the area of Islamic economics which aims to benefit the people. Allah SWT has order certain limits on human behavior so that it benefits individuals without sacrificing other individual rights.

Allah Almighty sent down is all easy in its laws. Islamic laws (both aqeedah and muamalah) are built on convenience, these religious norms are entirely loved (by Allah) but the easy ones are all the most loved by Allah. Hadith from Ibn Abbas (may Allah be pleased with him), Rasulullah SAW. once asked: "What religion is most loved by Allah Azza wa Jalla? He replied:" Al-Hanifiyah As-Samhah "(the straight and the easy). Therefore, it must not complicate itself in carrying out the religion of God and neither should makes it difficult for the servants of Allah, even though it does not aim for it, because the Messenger of Allah said: "Make it easy, do not make it difficult and make people flee (from the truth) and help each other (in carrying out tasks) and do not disagree" (HR. Bukhari and Muslim). The characteristic of Islam in terms of muamalah is muamalah syar'iyyah standing on the principle of making it easy for humans, compassion for all of them (Saiful Anwar, 2018). This ease can be seen in the form of tolerance in buying and selling, debt and bills, and the laws. 
There are several verses of the Al Quran that can be used as a foundation for humanity in acceptance information technology. QS Al Anbiya (21: 80 ) :

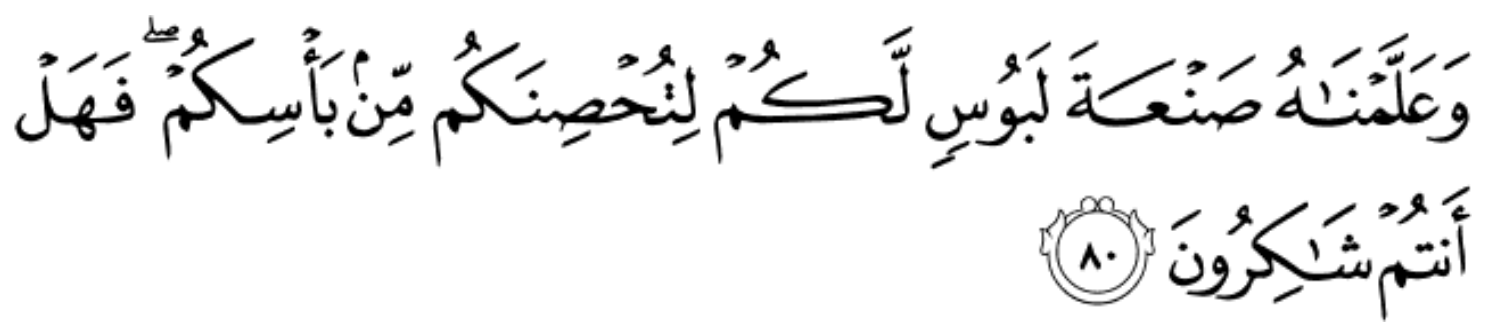

"And We taught him the making of coats (armory) for you, that you might protect you during your battles. Then, are you the ones who are grateful?"

Hereafter, QS Al Al'aq (96:1-5)

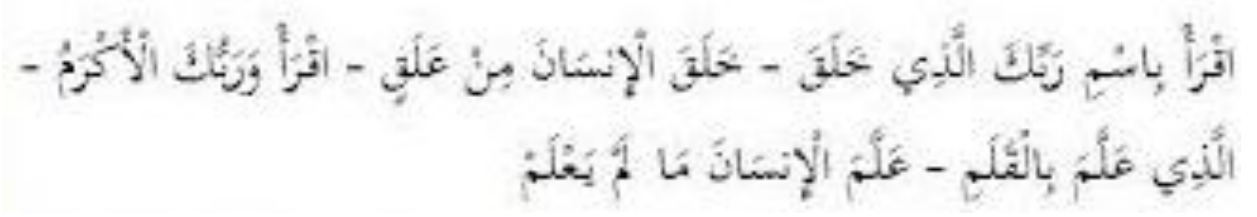

"Read! In the Name of your Lord, Who has created (all that exists), Has created man from a clot. Read! And your Lord is the Most Generous, Who has taugh (the writing) by the pen. Has taugh man that which he knew not "

Rasulullah SAW. said, "Allah has forgiven the man of the ummah before you first, he easily buys, easily buys and easily decides" (Hadith narrated by Tirmidhi and Ahmad from Jabir's hadith) and other traditions that can be used. Therefore, one of the principles that must be held in developing Islamic Economics is the ease and simplicity in the concept of theory and practice of banking services.

Syaikh Al Hilali explained that Islam is a religion that gives many conveniences to ummah. Those conveniences is also included in the subject of Islamic economics which aims to give benefit for the people. Allah SWT has set certain limits on human behavior so that it benefits individuals without sacrificing other individual rights.

Islam strongly supports to people who discover new things for the sake for ummah. Also for progress and ggive positive effect on the lives of their people. At present, technology is increasingly advanced so that many involve technology to complete its activities. In Islam, science and technology are very important to build a strong and resilient civilization. As was the case in the past the caliphs encouraged Muslims to create technology and make scientific work to develop and utilize existing natural resources. Therefore, science and technology from view of Islam is mubbah as long as it provides benefits to ummah.

\section{Economic Value Added for Banking Industry}

Based on Indonesia Internet Service Providers Association ( APJII ) survey in 2018, Java has the largest number of internet users. For more details, see chart below : 


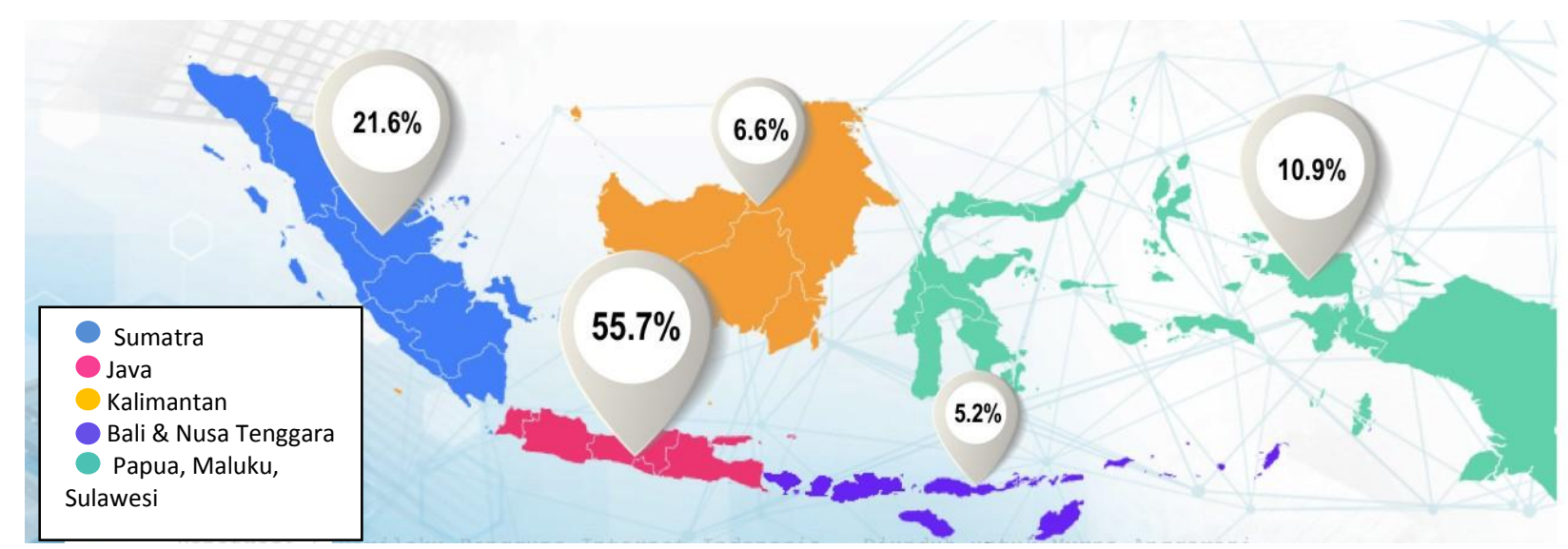

Figure 1. Percentage Internet Users in Indonesia

Source : on Indonesia Internet Service Provider Association, 2020 ( APJII )

Internet access is mostly enjoyed in the capital and provincial capitals such as Jakarta as a capital city, Surabaya in East Java, Semarang in Central Java, Yogyakarta in Special Region, Bandung in West Java, Medan in North Sumatra, Padang in West Sumatra and Makassar in South Sulawesi.

The penetration of internet has produced a profound transformation of the customer behaviour. Customers becoming increasingly used to interacting via digital media, include financial service. This phenomenon has provided a focus on customers in accelerating of customers needed.

According to Haller and Stolowy (1995) Value Added (VA) is a measurement of the performance of economic entities that have a long history of applications in economics. The meaning of added value is the difference between the value of the output of a company or an industry, namely the total income received from the sale of that output, and the input costs of raw materials, components or services purchased to produce these components. Added value is the value added by a company to the materials and services that it purchases through its production and marketing efforts. Added value is known by looking at the difference between the output value and the input value of an industry.

Value added will generally measured based on customer demand with results in the form of satisfaction from the services provided by the company to customers. In the production process in manufacturing, the customer can be interpreted as the recipient of the process we have done. Customer satisfaction is not necessarily measured by price but can also be measured by time and work that is not difficult for the recipients of our work.

According to Norman M Scarborough and Thomas Zimmerer (1984), the value added of a company can be created and improved in the following ways:

a. Developing new technology,

b. Discovering new knowledge,

c. Improving existing products or services, and

d. Finding different ways of providing more goods and services with fewer resources.

The role of information technology becomes a very important aspect considering the increasingly high use of mobile devices and computers as a medium of financial transactions. This was also supported by the increasing use of internet networks in Indonesia, which was followed by the expansion of internet network infrastructure development. The use of Information Technology is one of the prerequisites in providing financial services by the Bank. The use of Information Technology can be done by the Bank, either by developing supporting infrastructure independently or through cooperation with Bank partners. By 
utilizing Information Technology, the Bank is expected to be able to provide services to customers without limitation of place and time, and with minimal costs that provide maximum comfort to customers in accordance with customer preferences.

In the banking industry, service is important because the main product of a bank is a service to serve the financial transactions of its customers. Without high quality services, the bank will be abandoned by its customers. The formulation of the prime service strategy is one of the real elements of the "differentiator" that needs to be made to be able to realize competitive advantage in this decade. While consumer perceptions of the value and quality of a product (goods and services) are much influenced by excellent service as an attribute inherent in the core product itself. Therefore, for the banking world, service quality needs special attention in order to compete with other banks.

Expanding of public financial access, among others, through the opening of savings accounts in banks that can be done independently and improving financial services to facilitate customer financial management. This thing can increase the value added of a company.Value added of a product in the banking business has one goal, which is that the product can be developed continuously or its long-term sustainability. In this case it can be said that the product has a clear and massive market share.

\section{Changing Customer Behavior}

Danyali (2018) found indicated that the perceived advantage of using mobile banking, the influence of peer groups, source facilitator conditions as well as technology had the highest correlation. Among the influential components on attitude, the highest level belongs to perceived advantage of using mobile bank. Among the effective factors on behavioral control, source facilitator conditions and technology facilitator conditions had the highest correlation.

Digital banking has evolved as a wireless communication interface for producing value by customers in banking transactions. One of the substantially remarkable modern techniques in providing banking services is the provision of financial and banking services by using smart phones. Although the life of using smart phones for banking and financial operations is not too long, significant advancements have been observed in this area within a short time, which could highly promise the extensive development of this modern electronic banking technique in future.

The development of science is rapidly increasing, many emerging new terms or concepts. The concept or term arises because of practices or habits that are different from previous habits. The concept that arises because of the development of science, especially in the socio-economic field, namely cashless society. This concept may sound unfamiliar, but without realizing it will gradually become a common thing in everyday life.

The concept of cashless society is the changing from the use of hard cash in activities to electronic systems. This electronic system becomes an alternative media for the public in carrying out financial transactions. Online financial transactions include e-payment, transfer, barcode scanning and quick respond code.

Aside from being a new concept of payment, cashless society is also a new structure in society. The structure no longer views money physically as something that must be in the form of paper and metal. The form of money can be in the form of e-money in digital form. However, this does not mean negating money as a transaction medium. It only replaces the physical form (Hendrickson, 1972).

In other way, cashless society also is a new perception of the community in looking at the nature of money. Its use is related to various transactions. Money is not only seen as a physical form of payment. For detail, see chart below : 


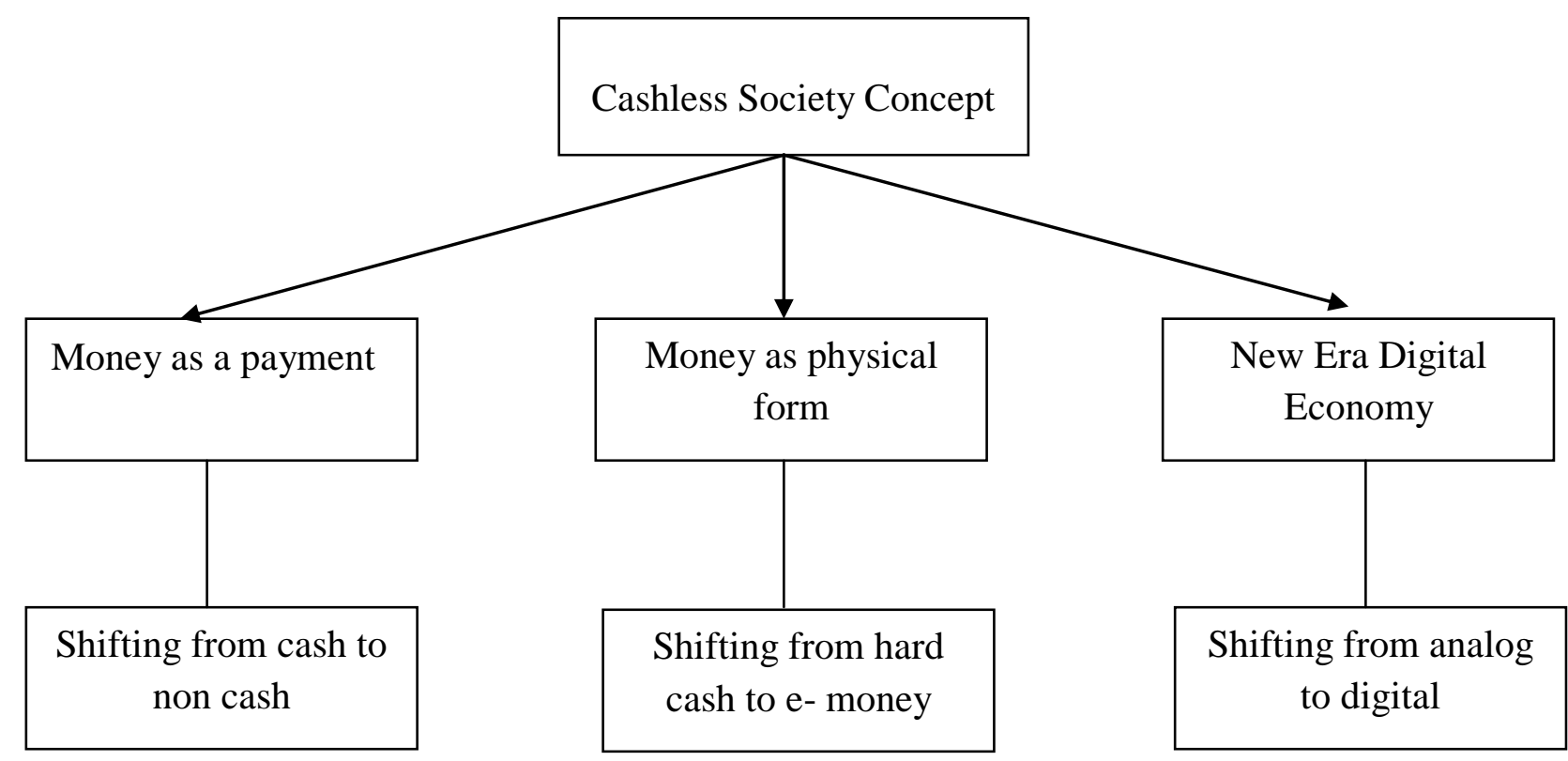

Figure 2. Changing Customer Behavior

From the chart above, there's a change in mindset regarding the use of money. This change is due to the e-money transition. E-money integrated in the gadget has the same function as cash. Daily life has been found to shift the use of cash into e-money. The purpose of using e-money is so that it can be used in the time used to transaction.

There are several factors that become the background of the emergence of cashless society in addition to technological advances. These factors are:

a. Circulation of physical money has the potential to increase the circulation of counterfeit money syndicates,

b. Awareness of the use of non-cash money will make it easier to trace the use of the money. This helps the government manage and oversee financial transactions in economic and trade activities. Money laundering prevention and reporting can be monitored through various accesses to electronic financial reports,

c. Support the government in dealing with corruption, bribery, and illegal payments.

Related with those factors, cashless society become an important thing in the digital economy. The concept of cashless society migh unfamiliar in Indonesia, but its expected that the application of non-cash economic activities and activities will be more widespread. Many countries in Europe and America have widely implemented non-cash transactions. Non-cash transactions are used in trade transactions, economic, and public service activities (Dalebrant, 2016).

Create cashless society in Indonesia requires roles from the government, the banking industry, and society. The role of the government is making regulations related to digital banking, as a coordinator between institutions or institutions related to the financial sector, and as an authority that can create supporting systems for digital economy platforms. The banking industry acts as a change agent in spearheading changes in society. Society as an end user, has a role as a policy supporter of the government and users of various banking products related to digital banking. For more details, see chart below : 


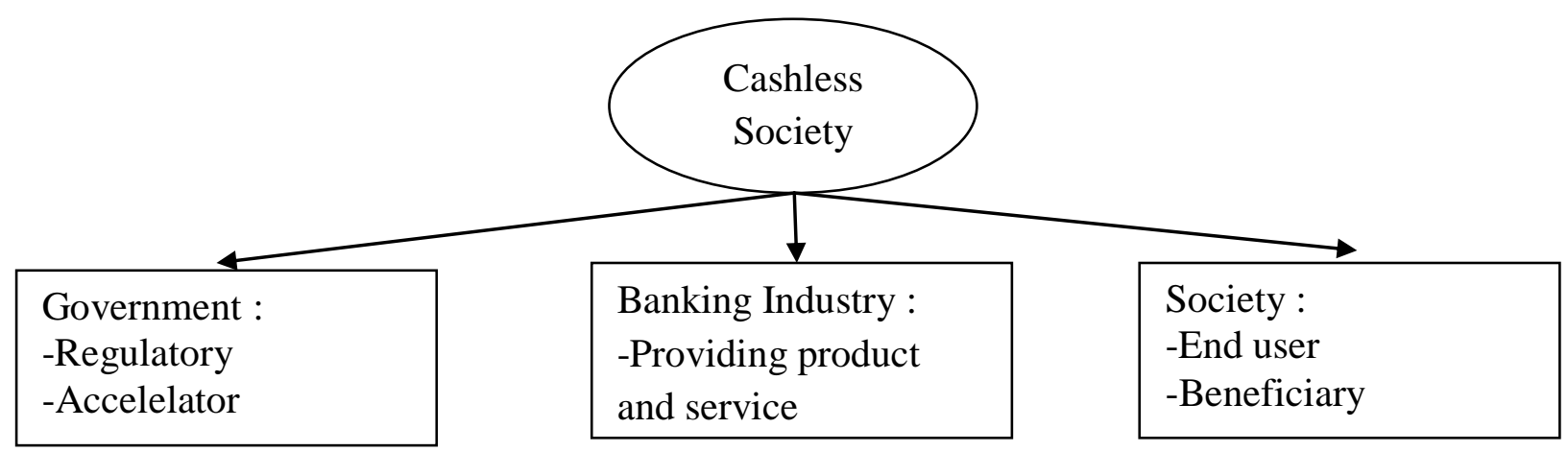

Figure 3. Role of Government, Banking Industry, and Society

Banking industry exists to provide a wide variety products to individuals, businesses or both. Bank must be able to know which product is most appropriate for serving a specific need to customer. It's important to understand the difference between the types of customer and the purposes they serve.

Government has a role as regulatory and accelelator for support cashless transaction. Government released 'Go Digital Vision 2020" for support National Non-Cash Movement. Through press releases in 2014, Bank Indonesia noted to endorse electronic transactions and augment payment system infrastructure in order to create and maintain an efficient, secure and reliable payment system by upholding aspects of consumer protection as well as broadening access to the payment system in the national interest. In addition, Bank Indonesia will formulate centralised payments for utility bills and encourage the government to utilise coordinated electronic payment instruments more actively. In that context, an integrated Electronic Bill Presentment System and an integrated payment service between payment networks will be developed.

\section{CONCLUSION}

Nowadays, development of information technology has a positive impact to society life. Innovation of technology have emerge, including for banking industry. In the banking industry, easiness and effectiveness makes customers more attractive. It's makes technology can be part of daily community activities.

In the concept of Islamic Economics, there are four philosophical foundations namely monotheism, justice and balance, freedom, and accountability. Freedom implies that humans are free to carry out economic activities as long as there is no provision from God prohibiting them. This shows that the existence of innovation, creativity, and technological development in the economy is a must. Islamic economic activities, must follow the conditions set out, including the use of digital banking.

Digital banking is not only that digital information as a media for communication but can also increase corporate profits. The company's profit is mainly in the banking industry. This is because customers are starting to use digital media for financial activities. Community behavior in economic activity gradually changes along with the use of digital media. This is interesting to analyze about technology-based banking applications that can change human behavior. 
In the era of digital banking, a new social order has emerged, namely the cashless society. The government supports cashless society because this is one of the government's goals in achieving the Digital Society.

The development of the use of information technology by the banking industry including through digital banking facilities. Digital banking was created to provide benefits to both the customer and the bank. In the future, banks will invest more in information systems and artificial intelligence because they can save costs, improve the quality of products and services, and efficiency.

Many benefits can be felt by customers by using digital banking. This is mainly seen from the amount of time and effort that can be saved because transactions using digital banking can be done anywhere as long as the user has supporting facilities to carry out the ebanking service. The many benefits of using digital banking, it can be predicted that its users will increase from year by year.

\section{REFERENCES}

Afandi, Yazid. (2009). Fiqih Muamalah. Yogyakarta : Logung Pustaka

Budi, Agus Riswandi. (2005). Aspek Hukum Internet Banking. Jakarta : Raja Grafindo

Cooper, Karyn. White, Robert E. (2012). Qualitative Research in the Post-Modern Era.New York: Springer

Costa C. and Grauwe, Paul De. (2001). Monetary Policy In A Cashless Society.International Macroeconomics. Centre For Economic Policy Research Discussion Paper, No. 2696

Dalebrant, Therése. (2016). The Monetary Policy Effects of Sweden's Transition Towards a Cashless Society: An Econometric Analysis. Berkeley : Departement Of Economics, University of California

Haller, Axel. Herve Stolowy. (1995). Value Added Accounting in Germany and France: A Conceptual and Empirical Comparison. Annual Congress of the European Accounting Association. Birmingham, United Kingdom, May 10-2. campus.hec.fr.

Hendrickson, Robert A. ( 1972). The Cashless Society. New York : Dood Mead

Huda, Nurul, dan Ahmad Muti. (2011). Keuangan Publik Islami : Pendekatan Al-Kharaj (Imam Abu Yusuf ). Bogor : Penerbit Ghalias

King, Brett. ( 2018 ). Bank 4.0 : Banking Everywhere : Never at Bank. Singapore : Marchall

Cavendish International

Mukhlis, Imam. (2015). Ekonomi Keuangan \& Perbankan. Jakarta: Salemba Empat

Nurul Huda, dkk. (2017). Ekonomi Pembangunan Islam. Jakarta : Kencana . (2019). Keuangan Publik Islam : Pendekatan Teoretis dan Sejarah. Jakarta :

Prenadamedia Grup

Riswandi, Budi Agus. (2005). Aspek Hukum Internet Banking. Yogyakarta : Persada

Sugiyono. (2016). Metode Penelitian: Kuantitatid, Kualitatif, dan R\&D. Bandung: Alfabeta

Stainback, Susan. Stainback, William. (1988). Understanding \& Conducting Qualitative Research. Iowa: Kendall/Hunt Publishing Company

Wolman, David. ( 2012 ). The end of Money. London : Da Capo Press

Yusuf, Muri.(2017). Metode Penelitian Kuantitatif, Kualitatif \& Penelitian Gabungan.Jakarta: Kencana

Zahro, Ahmad.(2016). Fiqih Kontemporer. Jakarta: Qaf Media

Chrismastianto, I. A. W. (2017). Analisis SWOT Implementasi Tekonologi Finansial terhadap Kualitas Layanan Perbankan di Indonesia. Jurnal Ekonomi dan Bisnis, 20(1), 133-144.

Cuesta, C., Ruesta, M., Tuesta, D., \& Urbiola, P. (2015). The digital transformation of the banking industry. BBVA Research 
Larsson, A., \& Viitaoja, Y. (2017). Building customer loyalty in digital banking. International Journal of Bank Marketing

Mbama, C. I., Ezepue, P., Alboul, L., \& Beer, M. (2018). Digital banking, customer experience and financial performance. Journal of Research in Interactive Marketing.

Scarborough, Norman M and Thomas Zimmerer. (1984). Effective Small Business Management. Columbus : C.E Merril Pub.Co

Selvaraj, P., \& Ragesh, T. V. (2018). Innovative approach of a regional rural bank in adopting technology banking and improving service quality leading to better digital banking. Vinimaya, 39(1), 22-32.

Tayibnapis, A. Z., Wuryaningsih, L. E., \& Gora, R. (2018). The Development of Digital Economy in Indonesia. IJMBS International Journal of Management and Business Studies, 8(3), 14-18.

Vebiana, V. (2018, October). Perbankan Digital, Pengalaman Pelanggan, dan Kinerja Keuangan Bank Syariah. In Prosiding Industrial Research Workshop and National Seminar (Vol. 9, pp. 747-751)

Ahmadi Danyali, A. (2018), "Factors influencing customers' change of behaviors from online banking to mobile banking in Tejarat Bank, Iran", Journal of Organizational Change Management,_Vol. 31 No. 6, pp. 1226-1233 